Correspondence between George T. Wright and A. T. Jackson Regarding Late 1930s-Early 1940s Excavations at the Sam Kaufman Site (41RR16)

Timothy K. Perttula

Heritage Research Center, Stephen F. Austin State University

Follow this and additional works at: https://scholarworks.sfasu.edu/ita

Part of the American Material Culture Commons, Archaeological Anthropology Commons, Environmental Studies Commons, Other American Studies Commons, Other Arts and Humanities Commons, Other History of Art, Architecture, and Archaeology Commons, and the United States History Commons

Tell us how this article helped you.

This Article is brought to you for free and open access by the Center for Regional Heritage Research at SFA ScholarWorks. It has been accepted for inclusion in Index of Texas Archaeology: Open Access Gray Literature from the Lone Star State by an authorized editor of SFA ScholarWorks. For more information, please contact cdsscholarworks@sfasu.edu. 
Correspondence between George T. Wright and A. T. Jackson Regarding Late 1930s-Early 1940s Excavations at the Sam Kaufman Site (41RR16)

\section{Creative Commons License}

\section{(c) (1) \&}

This work is licensed under a Creative Commons Attribution-NonCommercial 4.0 International License 


\title{
Correspondence between George T. Wright and A. T. Jackson Regarding Late 1930s-Early 1940s Excavations at the Sam Kaufman Site (41RR16)
}

\author{
Timothy K. Perttula
}

\section{Introduction}

In the 1930s and 1940s George T. Wright was a landowner (Kiomatia Plantation) and Vice-President of the Kiomitia Mercantile Company: General Merchandise in Kiomatia and Paris, Texas. He was also an avid Indian artifact collector at sites along the Red River in Red River, Texas, and also dug at sites he knew in the area, including the Wright Plantation site (41RR7), which he owned, and the Sam Coffman site (now known as Sam Kaufman, 41RR16, and for a short time known as the Arnold Roitsch site), a few miles downstream along the Red River (Figure 1). Both sites are large ancestral Caddo mound and village sites. Little professional archaeological work has ever been conducted at the Wright Plantation site, but there have been a number of archaeological investigations in mound (East and West mounds), habitation, and burial features at Sam Kaufman since the 1950s (Harris 1953; Skinner et al. 1969; Perttula 2008). The site was occupied by Caddo peoples as early as ca. A.D. 1000 to as late as the early $18^{\text {th }}$ century.

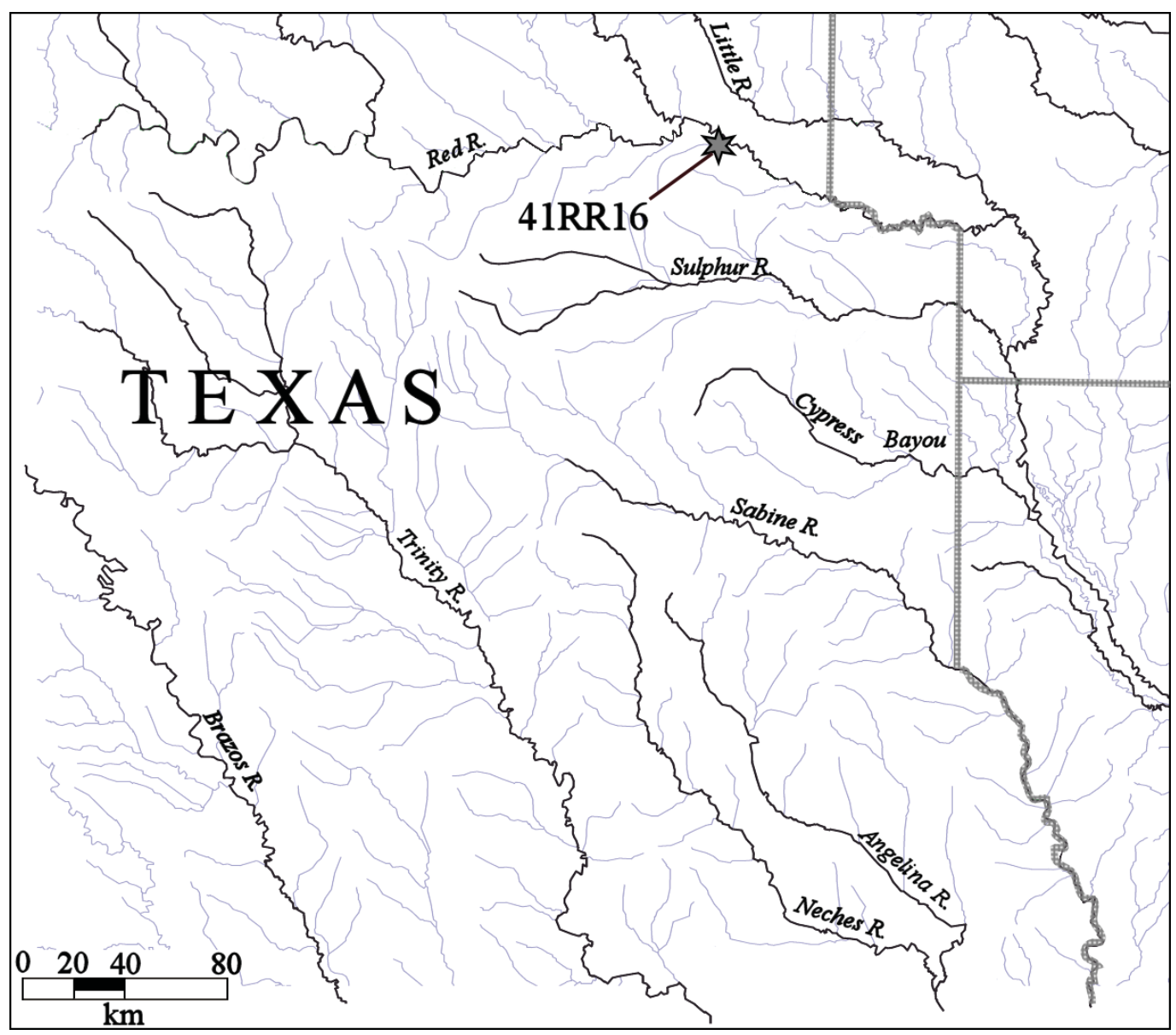

Figure 1. The location of the Sam Kaufman site (41RR16) in Eat Texas. 
Between 1941-1942, Wright was engaged in considerable correspondence with Alvin T. Jackson (18951974), a newspaperman turned archaeologist for The University of Texas at Austin (UT). Jackson worked for UT from 1929-1942, after which he spent about 13 years working for the Austin Railway System (lib. utexas.edu, A Guide to the Alvin Thomas Jackson papers, 1847-1970). Jackson apparently met Wright in 1931 when UT was investigating the Sanders site (41LR2) in Lamar County, Texas.

The correspondence on file at the Texas Archeological Research Laboratory at The University of Texas (TARL) between Jackson and Wright concerned investigations Wright and friends had recently been involved in at the Sam Coffman site. This work has not been previously discussed in the archaeological literature regarding the Sam Kaufman site, but is presented herein because it sheds new light on the archaeology of the site, especially the archaeology of the East Mound (see Skinner et al. 1969; Perttula 2008, 2017:140-143).

\section{Correspondence}

The correspondence between Wright and Jackson began with a January 27, 1941 letter concerning an artifact Wright had found in a burial at the Sam Coffman site:

January 27, 1941

My dear Mr. Jackson,

I am sending you today under separate cover a small artifact I recently excavated from a grave a few miles below my farm [the Wright Plantation]. It was in bad shape when I found it and it looks like the dryer it becomes the worse shape it gets in until now I am afraid to touch it...

The plow had just about ruined the small cemetery where I got this and the little that was left would not have lasted over a year or two longer...

Apparently, there were two of these objects, one on each side of the head, but the other seems to have completely disintegrated, leaving only a green blob of dirt which is still stuck to the skull...

This is the only piece of copper ever found in the county [Red River County] that I know of.

Cordially yours,

George T. Wright

January 28, 1941

Mr. George T. Wright

190 Bonham

Paris, Texas

Dear Mr. Wright:

Your letter of January $27^{\text {th }}$ and the package containing the copper covered specimen arrived this morning...Judging from the information contained in your letter and from the general shape and similarity of this specimen to two copper covered ear plugs found at the Sanders 
site in Lamar County, I am inclined to think that the specimens you recently found may have been worn as ear ornaments.

The material beneath the copper covering is a very light and fairly well preserved wood. It is suggestive of cottonwood, but has not as yet been identified...

Cordially yours,

T. Jackson

February 8, 1941

Dear Mr. Jackson:

I finally got to cleaning up my skull yesterday...The copper stain on the right head side may be copper stuck to the bone or just copper stained bone...

Cordially,

George T. Wright

February 14, 1941

Mr. George T. Wright

190 Bonham Street

Paris, Texas

Dear Mr. Wright:

...We have been unable to secure exact identification of the wood in the copper-covered earplug. It was my idea that it might be cottonwood. I am, however, advised by Dr. B. C. Tharp, Professor of Botany at the University, that there are several Texas woods that, if subjected to prolonged burial under conditions such as surrounded this specimen, might be equally light. He feels that, due to the condition of the wood, certain identification is almost impossible...

Due to the fact that this is an unusual specimen and one of considerable archaeological interest, I am wondering if you might consider donating or leaving it as an indefinite loan with the Anthropology Museum... [the copper-covered ear ornaments were not donated to $\mathrm{UT}]$.

Cordially yours,

T. Jackson 
February 17, 1941

My dear Mr. Jackson:

...It may be of further interest to you to know what else was buried with this skeleton. Four pieces of pottery, none of any particular potter that would mark it odd or outstanding. This includes one small...flattish bottle with a bulbous neck. This was buried right between the legs in the crotch. Another bottle, by the way, was found in a similar location with another skeleton. At the waist, or hips, were two rather kidney shaped "nodules" of bone that had been much polished, as shown by the undisintegrated end of one, $31 / 4$ " x $21 / 4$ " x $11 / 2$ ". These were pretty soft and badly eroded. Evidently they were cut out of a large animal bone-buffalo at a guess. These we took to be pot smoothers. Also with these, was a bone needle about 6 " long, polished and smoothed. This would lead me to believe the skeleton was that of a woman. Another thing you will want to know - this grave was in the eastern or smaller mound (East Mound] on the Coffman farm (Figure 2) about 10 miles below my farm [at Wright Plantation] [the East Mound was $1 \mathrm{~m}$ in height in 1991]. There are two

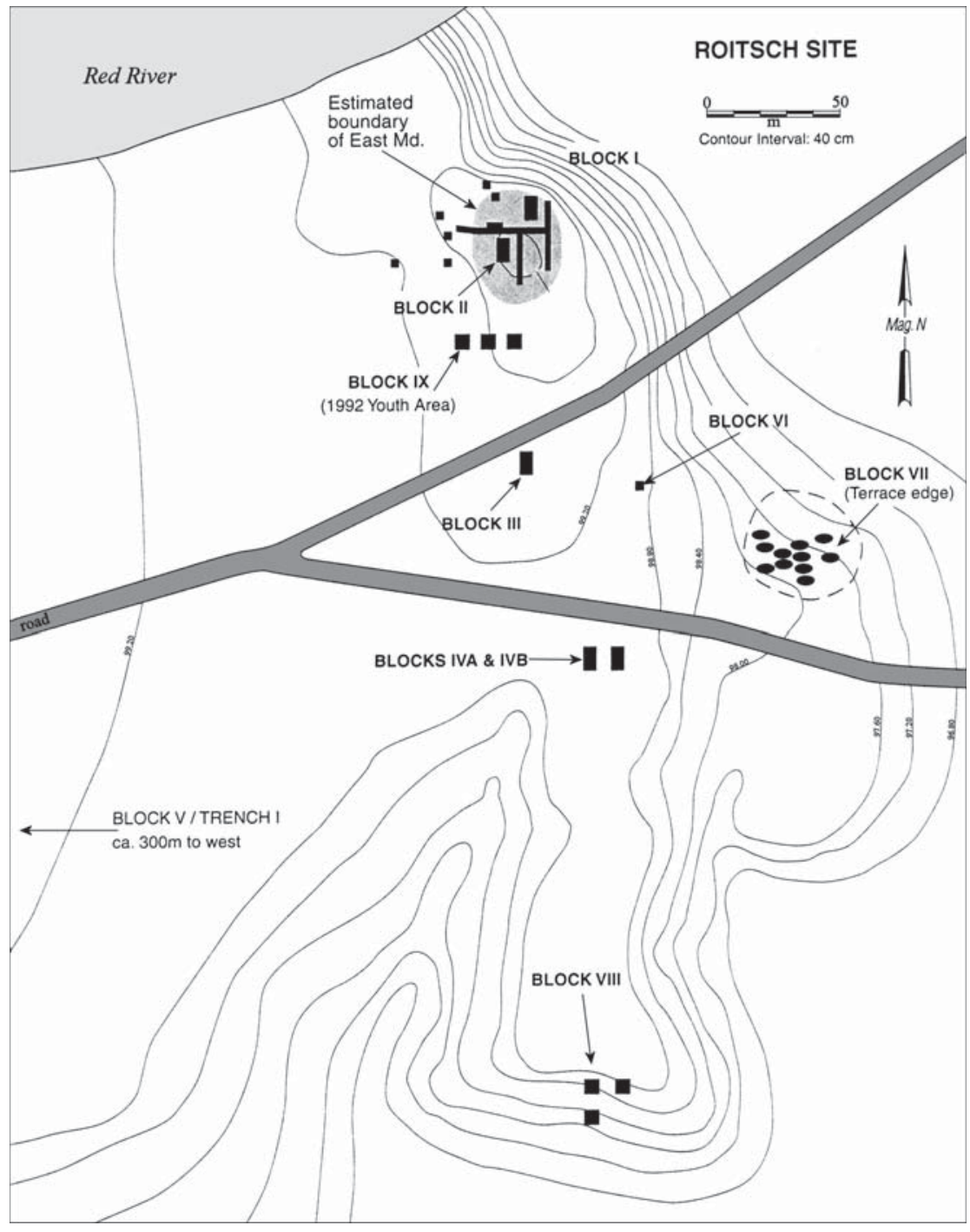

Figure 2. Plan map of the eastern part of the Sam Kaufman site (after Perttula 2008:Figure 5; see also Skinner et al. 1969:Figures 3 and 5). 
mounds there you know, similar in most every way to those at Direct [Sanders site, 41LR2] but smaller. I told you about these the last time I saw you. This skeleton was in the center of the mound, and about $21 / 2$ [feet] deep - the deepest burial I found.

I was down there yesterday and was able to secure one very small pot and the pieces of some 4 or 5 more. The place had just been plowed and this time I think the plow got the last grave. All the burials seem to have been in the N. E. or down-the-river quarter of the mound.

I looked over the bigger mound [West Mound] about 300 yards above the burial mound. It had just been plowed. They are plowing up charcoal in quantities and larger chunks, lots of red ashes and one big load of white ashes, a few bones (probably not human) but no graves. It looks very interesting and won't last long [the West Mound was lost to erosion in 1990].

Cordially yours,

George T. Wright

February 29, 1941

Mr. George T. Wright

190 Bonham Street

Paris, Texas

Dear Mr. Wright:

Thanks for your letter of February $17^{\text {th }}$ in which you give additional information in regard to the site and burial in which the copper covered wooden ear plug was found...

With regard to the pottery found in the grave with the ear plugs, I am wondering if any of the vessels are redware and if they show any resemblance to the redware found at the T. M. Sanders site. I am very much interested in this matter in view of the fact that we are now preparing for publication a report on the Sanders work [this report was not actually published until 2000, Jackson et al. 2000].

It is indeed unfortunate that the burials you mentioned are being destroyed by cultivation. We would very much like to work that site, but it seems impossible in the near future.

Sincerely,

A. T. Jackson

March 10, 1941

My dear Mr. Jackson,

I have your letter asking what red ware was found in the Coffman mound. Only two red pieces were outstanding: one a large cuspidor type (Figure 3a; see also Dowd 2011:Figure 5.8, left], $11 \mathrm{in.} \mathrm{high} \mathrm{and} 10 \mathrm{in}$. across. It was decorated with a $21 / 2 \mathrm{in.} \mathrm{band} \mathrm{with} \mathrm{rising} \mathrm{sun}$ symbols [Avery Engraved] and by the center of the collar was another $21 / 2$ in. band with 
other decoration. The bowl takes up about half the length of the vessel and the flaring mouth the other half. This piece, although it was filled with sand, was bottom side up and was taken out whole...The other nice piece was a 6 in. jar rather similar. The bowl, although it has a small flat bottom, is perfectly globular and underneath there is a $11 / 2$ in. collar to form the mouth. This is decorated with thumb prints and is four-scalloped at the rim. Then there were about half a dozen red jars of the flower pot type from 6 in. high to 2 in.

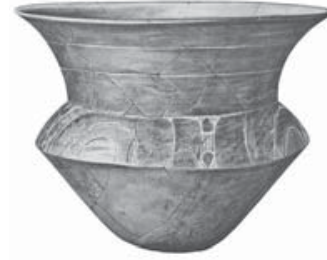

a

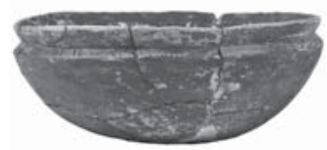

e

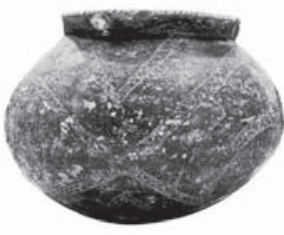

b

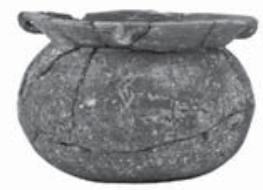

$\mathrm{f}$

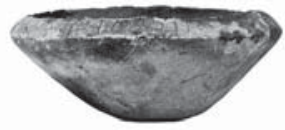

$\mathrm{c}$

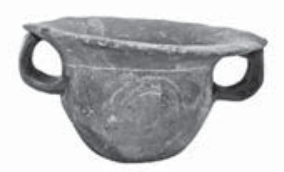

$\mathrm{g}$

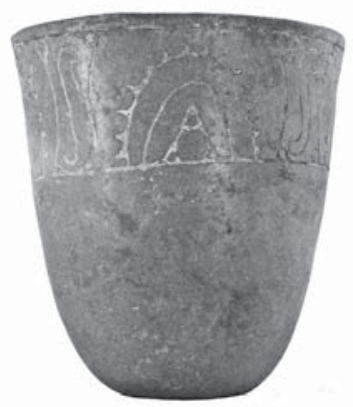

d

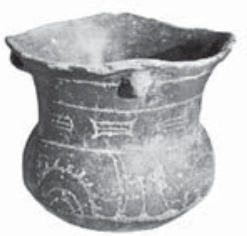

$\mathrm{h}$

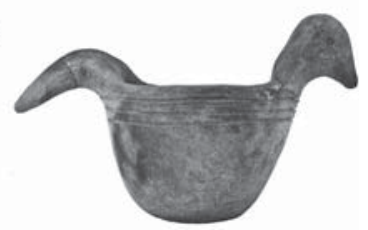

i

Figure 3. McCurtain phase fine ware vessels: a, d, h, Avery Engraved; b, Hudson Engraved; c, Simms Engraved; e, Simms Engraved, var. Darco; f-g, engraved jars; i, engraved effigy bowl. Provenience: Foster Place (3LA27; from Moore 1912:Plate 43); b, e-f, Sam Kaufman (41RR16); c-d, g, i, Boyce Smith collection from Red River sites; h, Jim Clark site, Red River County, Texas.

If you are interested in other information regarding this site, there are several peculiarities that might be noted. Six bottles were recovered, all flattish with bulbous necks [likely Hudson Engraved, see Harris 1953:Plate 5:1-2, 5-7; Skinner et al. 1969:Figure 16a, e], all small and with the usual scroll designs. About a dozen shallow bowls in various stages of decay - some almost entirely gone and two perfect ones. The edges of these were decorated with oblique, small incisions, as were the rims of the bottles...

The burials were only in the NE or down-the-river quarter of the mound. We found probably a dozen graves which, I judge, is about $1 / 3$ of the original cemetery. All the graves seem to have been on a level. That means those on the sides of the mound were all... [word undetermined]. The plow and consequent erosion has ruined them all. Most of the burials were in a stiff black dirt, very black and very waxy [Skinner et al. 1969:17 and Figure 4 mentions the black sandy clay zone as resting on the red clay B-horizon]. This was very hard on the pots, rotting them badly. This dirt had been hauled there for a considerable distance. Another feature is the peculiar and, in some instances, artistic use of the triangle or shield with which they were decorated on the sides of the common jars [Nash Neck Banded and/or Emory Punctated-Incised jars, see Harris 1953:Plate 8:5; Skinner et al. 1969:Figures 13h and 16j]. Some were scratched on, like a running band, others made separately and pressed on with thumb and forefinger. Others pushed up and made similar to a twisted cord. Some were very narrow and very long. These were the ...best made and most artistic of all... This triangle is very common in this district and I take it to be the totem or insignia of the tribe... 
Most of the pottery was badly broken and in some cases, only a third or two thirds of the vessel was there. And it never had been there. There may be something else in the mound but the dirt doesn't look like grave dirt to me...

From one plow-disturbed grave a I got most of the pieces of a small bowl [Simms Engraved, based on one vessel from the Sam Kaufman site in the TARL collections, donated by George T. Wright] with a very pretty and odd design on it. I am sending this to you asking you to please fix it up for me at your convenience... There is another one, whole, just like this one only much larger. The decorations are very nearly alike as though made by the same person. They came from different graves. One nice odd clay pipe [likely an elbow pipe form] was found.

Thanks

Geo. T. Wright

March 15, 1941

Mr. George T. Wright

190 Bonham Street

Paris, Texas

Dear Mr. Wright:

The pottery specimens you recently sent arrived in good shapes. The two small restorable vessels are now being worked on..

I am very much interested in this material for two reasons: first, since it comes from the site where the copper covered ear plug was found; and second, since the pottery is strikingly similar to certain vessels found [in 1932] in a historical burial site in Cass County near Atlanta [the Clements site, 41CS25, see Perttula 2015]...

Cordially yours,

A. T. Jackson

March 17, 1941

Dear Mr. Jackson:

...But since you seem really interested [in the Coffman site], I will add two more details that may mean something.

The last grave we ran into was well down the east side of the mound. the plow had all but wrecked it but in scratching around in the ... [word not determined] we found a small black shallow bowl, 3" deep by 4" wide, similar to the other specimens of this type from this location except the short rim flared slightly outward rather than perpendicular as the rest of them were [see Figure 3e, Simms Engraved, var. Darco]. On the edge of the rim were the usual oblique incisions. This was just an ordinary vessel, very thin and fragile. The upper part had a weak spot in it which caused it to crumble slightly but was restored 
nicely. I discovered a smaller shallow bowl 2" x 3", rather similar. After I had washed this one, I found a very peculiar marking or design on one side. I had had it cleaned up for a week before I noticed it. The bowl itself is heavily tempered with shell, thin, was particularly well made and has a slight decoration around the collar which is nothing to brag about (Figure 4). It has a thin black wash covering the entire bowl, inside and out. Half way between the center of the side and the bottom, lightly but very plainly scratched in the thin wash, was a design that surely had some meaning...I am sending you a drawing of the bowl and design...It measures nearly an inch in height.

The other interesting feature is a small "cup" that came from one of the earlier graves. It measures $11 / 2$ " x 2 ", is thick and rather heavy. While I do not remember anything of interest coming out of it when it was being cleaned, I note that the inside is quite green as if copper-stained [this vessel likely contained green glauconitic clay pigments that stained the vessel walls].

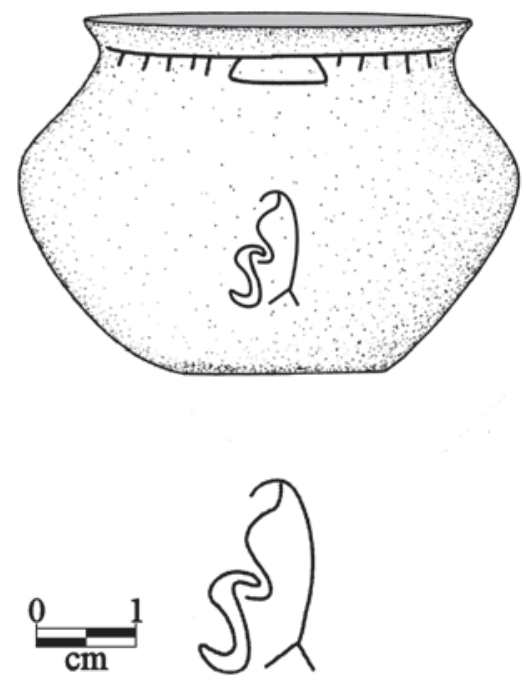

Figure 4. Drawing of vessel by George T. Wright from the Sam Coffman [Kaufman] site, East Mound.

\section{Cordially,}

\section{George T. Wright}

July 20, 1941

Mr. A. T. Jackson

University of Texas,

Austin, Texas,

Dear Mr. Jackson,

The other day, for want of something better to do, I went down and looked over the mound that I dug into last winter on the Coffman place below me. There have been some very hard rains this spring, and some more plowing. I thought maybe it might show up something new. And it did. The plow had wrecked another grave; torn it all to pieces except a small part which included the hips of the skeleton. While scratching around there, close up against the hips, were two objects which I am sending you by mail. You may keep them. One of these, as you see, is a small piece of iron, which tells us more about the graves than anything else I found.

Since you have shown considerable interest in this mound, I feel sure you will want to know about this as it is of considerable importance scientifically. There is no question but that these objects were buried with the skeleton as the bottom of a pot was only an inch or two away.

Cordially yours, 
July 22, 1941

Mr. George T. Wright

190 Bonham Street

Paris, Texas

Dear Mr. Wright:

Your letter and the two specimens were received today. Many thinks for your kindness in sending this information. The finding of the metal in the grave in the Coffman Mound bears out an idea I had, based on the materials you submitted a few months ago. This information furnishes another link in the chain of evidence that eventually will enable us to develop a dependable chronology for the northeast Texas region.

Sincerely,

A. T. Jackson

\section{Summary and Conclusions}

Correspondence in 1941 between George T. Wright, a prominent Red River landowner, owner of the Wright Plantation site (41RR7), and an avid collector and digger of Caddo Indian artifacts, and A. T. Jackson, UT archaeologist at the time, led to the sharing of information from Wright about excavations he had conducted at the East Mound at the Sam Coffman (or Kaufman) site some short time before the correspondence began. Wright and friends had excavated at least 12 ancestral Caddo burials from the northeast quadrant of the East Mound, all roughly at the same depth and the same general range of funerary objects, principally ceramic vessels. His description of the shape and decoration of the vessels are consistent with late McCurtain phase (ca. A.D. 1500-1700) ceramic styles, and the vessels may have been Avery Engraved, Hudson Engraved, Simms Engraved, Nash Neck Banded, and Emory Punctated-Incised types. Of particular interest to both Wright and Jackson was a copper-covered wood ear plug or spool from one of the burials, as well as another burial that had a piece of iron, possibly a fragment of a European trade good.

More recent excavations in the East Mound by Skinner et al. (1969:Figures 3 and 5) and the Texas Archeological Society in 1990 and 1991 (see Figure 2) encountered no ancestral Caddo burials in the northeast quarter of the mound, though there were pits and post holes in block and trench excavations (Figure 5). Skinner et al. (1969:26) also did not find any evidence of burials in the northeast corner of the mound, although they did find and excavate Burials 3-5 a short distance east of the mound. These burials had Avery Engraved, Simms Engraved, Hudson Engraved, Keno Trailed, Nash Neck Banded, and Emory PunctatedIncised vessels, and thus these burial features are likely contemporaneous with the Late McCurtain phase burials excavated by Wright in the early 1940s. Interestingly, one of the burials (Burial 4) excavated by Skinner et al. (1969:26) "has a small sheet of copper by his left ear which left a green stain on the left side of the skull."

The main burial feature in the East Mound is a large $15^{\text {th }}$ to early $16^{\text {th }}$ century shaft tomb (4 $\mathrm{m}$ in diameter) that had been dug through the mound fill, the center of a burned structure floor (see Figure 5), and deep into the natural clay subsoil. This shaft tomb was for the burial of a prominent middle-aged adult male in the center of the tomb, a middle-aged adult female by his right side, and nine other individuals ranging from 13-14 years old to 36-50 years old at the time of their death. A wide range of funerary offerings were placed in the tomb, including ceramic vessels, arrow points, a large biface, stone ear spools, marine shell and turquoise beads, pearl beads, marine shell gorgets, discs, pendants, and inlays, mussel shell, drilled bear teeth, and three ground stone celts (Skinner et al. 1969:27, 30-35 and Figures 10-11). 


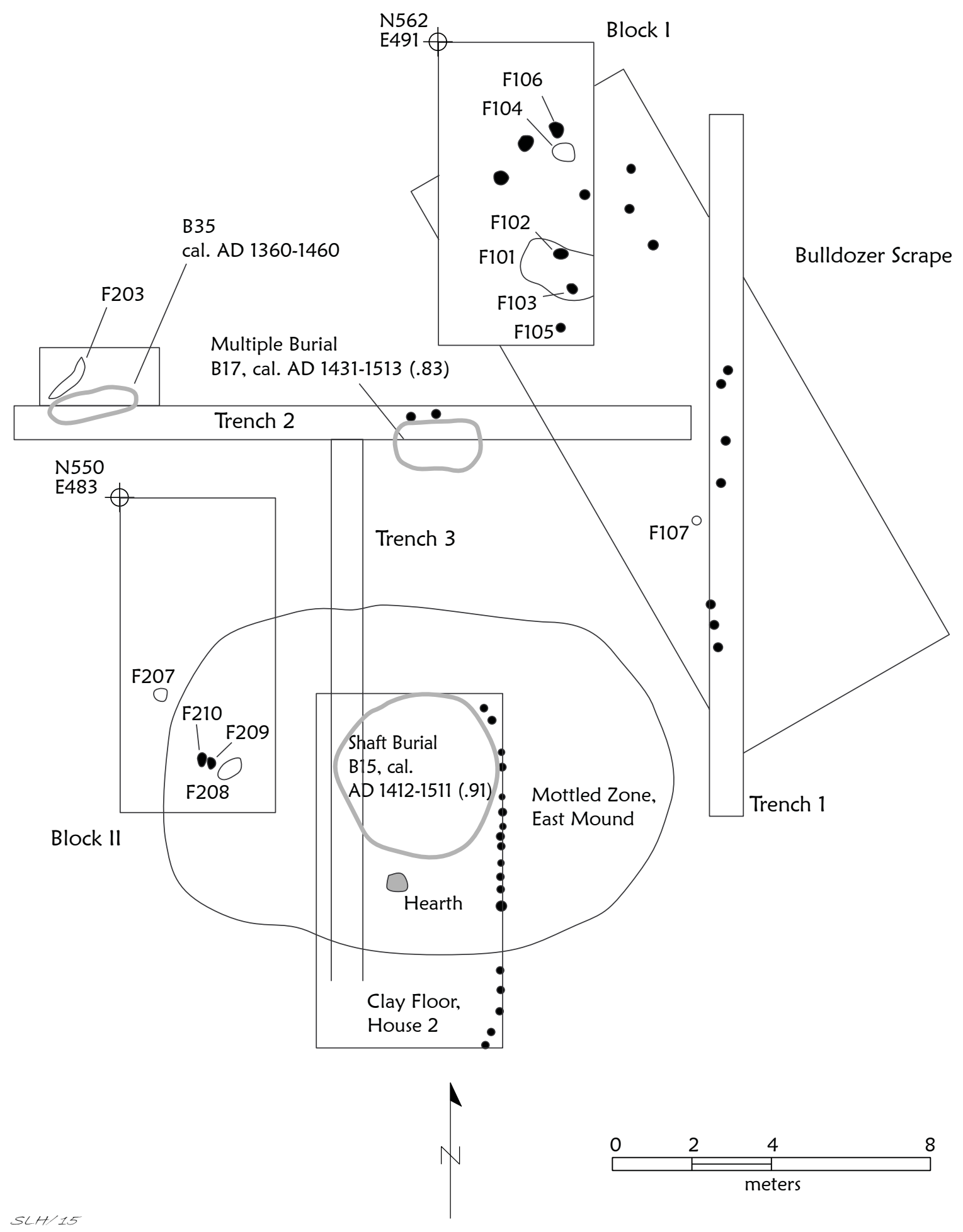

Figure 5. Features and block excavations on the East Mound (after Perttula2008:Figure 6). 
Wright had also mentioned possible bison bone tools in one of the burials he excavated at the Sam Kaufman site. More recent excavations in the McCurtain phase (ca. A.D. 1400-1680) archaeological deposits at the Sam Kaufman site recovered two animal bones from very large mammals, cf. Bos/Bison (Yates 2008:Table 47). Radiocarbon dates from the site from this component date the occupation from the early 15 th century to the early 17 th century A.D., although the recovery of glass beads from several burials at the site indicate that the occupation continued to at least ca. A.D. 1700-1730. Sam Kaufman is one of only 24 archaeological sites known in East Texas and Northwest Louisiana that have bison remains. Bison remains are common in East Texas sites only after ca. A.D. 1430.

Other than one Simms Engraved, var. Darco vessel donated to UT by George T. Wright, and presently in the TARL collections, the location of the remainder of Wright's collection from the Sam Kaufman site is held by the Sam Noble Oklahoma Museum of Natural History (SNOMNH) at the University of Oklahoma, as they hold more than 180 funerary objects from Red River County in the George T. Wright collection (Marc Levine, SNOMNH, May 2017 personal communication). These materials were documented in July 2017 as part of better understanding the use by Caddo peoples of the East Mound at the Sam Kaufman site.

\section{References Cited}

Dowd, E. L.

2011 Identifying Variation: A Stylistic Analysis of Four Caddo Pottery Assemblages from Southeastern Oklahoma. Memoir 15. Oklahoma Anthropological Society, Norman.

Harris, R. K.

1953 The Sam Kaufman Site, Red River County, Texas. Bulletin of the Texas Archeological Society 24:43-68.

Jackson, A. T., M. S. Goldstein, and A. D. Krieger

2000 The 1931 Excavations at the Sanders Site, Lamar County, Texas: Notes on the Fieldwork, Human Osteology, and Ceramics. Archival Series 2. Texas Archeological Research Laboratory, The University of Texas at Austin.

Moore, C. B.

1912 Some Aboriginal Sites on Red River. Journal of the Academy of Natural Sciences of Philadelphia 14(4):526-636.

Perttula, T. K.

2008 The Archeology of the Roitsch Site (41RR16), an Early to Historic Caddo Period Village on the Red River in Northeast Texas. In Collected Papers from Past East Texas Archeological Society Summer Field Schools, edited by T. K. Perttula, pp. 313-628. Special Publication No. 5. Texas Archeological Society, San Antonio.

2015 Caddo Ceramic Vessels from the Goode Hunt (41CS23) and Clements (41CS25) Sites in the East Texas Pineywoods. Special Publication No. 42. Friends of Northeast Texas Archaeology, Austin and Pittsburg.

2017 Caddo Landscapes in the East Texas Forests. Oxbow Books, Oxbow, England.

Skinner, S. A., R. K. Harris, and K. M. Anderson (editors)

1969 Archaeological Investigations at the Sam Kaufman Site, Red River County, Texas. Contributions in Anthropology No. 5. Department of Anthropology, Southern Methodist University, Dallas.

Yates, B. C.

2008 Observations on the Faunal Remains from the 1991 Field School on the Red River in Red River County, Texas. In Collected Papers from Past Texas Archeological Society Summer Field Schools, edited by T. K. Perttula, pp. 458-478. Special Publication No. 5. Texas Archeological Society, San Antonio. 